\title{
Geminin Coiled-Coil Domain-Containing Protein 1
}

National Cancer Institute

\section{Source}

National Cancer Institute. Geminin Coiled-Coil Domain-Containing Protein 1. NCI

Thesaurus. Code C126582.

Geminin coiled-coil domain-containing protein 1 (334 aa, $238 \mathrm{kDa}$ ) is encoded by the human GMNC gene. This protein is involved in the promotion of DNA replication. 